\title{
EEC Mineral Policy - Some Proposals for Change in the 1980s
}

\author{
Mike Faber, Carlos Fortin and Adrian Hewitt
}

The mineral sector is, prima facie, one in which there is a clear mutuality of interests between the EEC and the Third World. Europe relies heavily on imports for its requirements of mineral raw materials; a large proportion of those imports are from Africa, Asia and Latin America (see Table 1). In turn, a number of developing countries derive substantial proportions of their export revenue from their mining industries (see Table 2). Public sector cooperation could conceivably help develop the mining industries of the producing countries and increase their export revenue while providing security of supplies and stable prices to the consuming countries.

\section{Current EEC Policy}

This was the broad rationale behind the introduction in the Second Lomé Convention of the special scheme for mineral products known as Minex or Sysmin. More specifically, it reflected the concern amongst EEC members about the potential reduction in mineral supply from Africa because of lack of investment.

An official of the EEC Commission has described the objectives of the Community negotiators of the 'Minerals Product' chapter in the second ACP-EEC Convention in the following terms:

The envisaged measures should be compatible with the natural sovereignty of the ACP states over their domestic natural resources; they should form a package expressing a mutually beneficial interdependence; . . . the security of the mining investment would constitute only one of the elements along with the maintenance of the production and export capacities of existing mines,

Table 1

The European Community's sources of supplies of major non-fuel minerals and metals $1979-80$ averages in percentages

\begin{tabular}{|c|c|c|c|c|c|c|}
\hline & $\begin{array}{l}\text { domestic } \\
\text { production } \\
\text { or recovery }\end{array}$ & $\begin{array}{l}\text { developed } \\
\text { countries }\end{array}$ & $\begin{array}{l}\text { Eastern } \\
\text { bloc (inc } \\
\text { China) }\end{array}$ & $A C P$ & $\begin{array}{l}\text { other less } \\
\text { developed }\end{array}$ & unallocated \\
\hline Bauxite & 40 & 27 & 1 & 31 & 1 & .. \\
\hline Alumina & 74 & 4 & - & 20 & - & 2 \\
\hline Aluminium & 78 & 17 & 2 & 2 & - & 1 \\
\hline Copper & 20 & 20 & 5 & 29 & 26 & .. \\
\hline Iron Ore & 13 & 42 & - & 16 & 27 & 2 \\
\hline Lead & 56 & 28 & 1 & - & 9 & 6 \\
\hline Manganese & - & 53 & - & 31 & 12 & 4 \\
\hline Nickel & 13 & 50 & 13 & 13 & 10 & 1 \\
\hline Phosphates & - & 24 & 2 & 16 & 51 & 7 \\
\hline Tin & 7 & 5 & 2 & 8 & 73 & 5 \\
\hline Zinc & 43 & 36 & 2 & 1 & 14 & 4 \\
\hline $\begin{array}{l}\text { Weighted average } \\
\text { of above } \\
\text { products (a) }\end{array}$ & 20 & 33 & 3 & 22 & 19 & 2 \\
\hline
\end{tabular}

(a) weighted according to value of European consumption of each produce in its common form.

Source: derived from P. C. F. Crowson, Minerals Handbook 1982-83, Macmillan for the Royal Institute of International Affairs, London, 1982.

Bulletin, 1983. vol 14 no 3. Institute of Development Studies. Sussex 
Share of minerals in total merchandise exports 1980-81 and relevant ACP Sysmin dependence threshold

\begin{tabular}{|c|c|c|c|c|}
\hline \multirow[b]{2}{*}{ ACP state } & \multirow{2}{*}{$\begin{array}{c}\text { Sysmin } \\
\text { dependence } \\
\text { threshold (\%) }\end{array}$} & \multirow[b]{2}{*}{ product } & \multicolumn{2}{|c|}{$\begin{array}{c}\text { export } \\
\text { dependence } \\
\text { by products }(\%)\end{array}$} \\
\hline & & & 1980 & 1981 \\
\hline Zambia & 10 & Copper & 91.3 & 94.8 \\
\hline \multirow[t]{2}{*}{ Zaire } & 15 & Copper & 43.2 & 46.7 \\
\hline & & Cobalt & 21.1 & 19.1 \\
\hline Papua New Guinea & 10 & Copper & 45.1 & 49.5 \\
\hline Jamaica & 10 & Bauxite and alumina & 76.4 & 77.4 \\
\hline Surinam & 10 & Bauxite and alumina & 68.6 & 69.1 \\
\hline Guyana & 15 & Bauxite and alumina & 48.3 & 41.3 \\
\hline Guinea & 10 & Bauxite and alumina & $94.1^{1}$ & \\
\hline Mauritania & 10 & Iron ore & 77.8 & 64.6 \\
\hline Liberia & 15 & Iron ore & 52.7 & 62.4 \\
\hline Togo & 10 & Phosphates & 39.6 & $\ldots$ \\
\hline Senegal & 15 & Phosphates & 16.3 & $\cdots$ \\
\hline \multicolumn{5}{|c|}{ Mineral exports near but below threshold } \\
\hline Rwanda & 10 & Tin & 8.0 & $\cdots$ \\
\hline Gabon & 15 & Manganese & 7.1 & 6.5 \\
\hline \multicolumn{5}{|c|}{ Mineral exports above threshold but product excluded } \\
\hline Niger & & Uranium & 76.3 & \\
\hline Botswana & & Copper Nickel matte & 20.5 & 24.3 \\
\hline Zimbabwe & & Nickel and all ferrous products & $23.5^{2}$ & $19.5^{2}$ \\
\hline
\end{tabular}

... not available in IFS

Source: IMF International Financial Statistics, vol XXXV no 12, December 1982, except for Guinea and Zimbabwe

1 1979; figures from World Bank

${ }^{2}$ figures from Zimbabwe Monthly Digest of Statistics

financial support for exploration and productive investments, etc; increased involvement of public authorities in mineral development in order to create favourable conditions for the relaunching of mining activities, while recognising that those authorities could only act as a catalyst in generating private European capital and should not affect the traditional role of the mining companies; on the basis of these principles, the Lomé II Convention offers the means to safeguard existing production and export capacities against major disruptions beyond the control of the ACP states concerned, relaunch research and exploration efforts, and facilitate and stimulate investments in identified projects.

[Goldstein 1982:183]

Clearly, therefore, an important element in the Community's overall objectives was to respond to the demands of European mining companies, concerned both with access to resources to expand their involvement in ACP mining and, more particularly, with measures to increase the security of mining investment. While stopping short of accepting the more radical demands of the companies such as provisions for 'political risk' insurance and for sanctions against host governments that unilaterally alter the terms of mineral concession agreements, the Convention introduced two new instruments specifically designed to stimulate private investment.

First, it offered a new possibility for agreements relating to individual mining projects in the ACP countries where the Community contributes towards their financing. Such agreements, involving the Community, a member state and an ACP state would be designed to reconcile the concern of European operators about the security of their investment and 
operating conditions with the legitimate rights of the host country government. They would cover such matters as the financing of the project and its related infrastructure, distribution of the product, training obligations of the operator, guarantees that the terms of the agreement would only be altered in accordance with pre-agreed renegotiation clauses, and procedures for dealing with the settlement of difficulties, disputes and with the determination of compensation in the event of nationalisation. As an inducement to enter into such agreements, and as an additional contribution to the stabilisation of relations between partners in mining projects, the Convention also holds out the prospect of Community assistance in the financing of host country participation in the shareholding of mining enterprises developing the resources of ACP countries [EEC-ACP 1981, Title III, ch 2, article 58].

As a catalyst to stimulate private sector investment in mining, $200 \mathrm{mn}$ European Units of Account (EUAs) have been made available to the European Investment Bank (EIB) to enable it to participate in mining and energy projects of mutual interest to the Community and ACP countries, and the restriction previously placed on EIB interest rebates in the hard-rock mining sector has been lifted [EEC 1979].

In addition, available resources to assist exploration and prospecting and the development of knowledge about a specific deposit have been increased and diversified'. If the ACP states concerned decide to accord such projects the necessary development priority, they can call on loans or grants from the European Development Fund (EDF) to provide technical and financial assistance to strengthen the capacity of geological and mining divisions within ACP governments, and even to establish national or regional exploration funds (EEC-ACP 1981, Title III, ch 2, article 58). Separate from this provision, the amount of 'risk capital' available for the launching of mining projects has been increased from $95 \mathrm{mn}$ EUAs in Lomé I to $280 \mathrm{mn}$ EUAs in Lomé II, and the purposes for which such 'risk capital' can be used have been broadened to include a range of pre-production expenditures [EEC-ACP 1981, article 51].

\section{The Sysmin scheme}

But the main innovation in Lomé II with regard to minerals is the introduction of the Sysmin scheme, the stated aim of which is to contribute to the creation of a more solid basis for the development of ACP states largely dependent on their mining sectors. It is not, as Stabex is, a mechanism for automatic compensation of export losses, but it nevertheless provides a kind of limited insurance formula by helping to maintain production and export capacity when either is adversely affected by 'serious, temporary disruption ... beyond the control of the ACP states concerned'
[EEC-ACP 1981, article 49]. Declines in the capacity to produce or export can be classed under three heads: political (including involuntary political disruptions originating in neighbouring states); technical (including unforeseen physical difficulties at the mine such as floods and fire); or managerial (eg the unexpected departure of large numbers of qualified staff or some other forms of withdrawal of labour). But an application for funds may also be made to counter economic factors like abnormal reductions in prices or quantities exported which could adversely affect maintenance of plant. Sysmin is not intended, however, to subsidise mining operations which are not economically viable in the long term.

Eligibility for Sysmin coverage is limited to ACP states and, since the scheme operates on a product-byproduct basis, to those ACP countries which derive at least 15 per cent of their merchandise export earnings (10 per cent for the least developed, island and landlocked category) from the product. This is the so-called 'dependence threshold'. The seven minerals included in the scheme are copper - including associated cobalt production - phosphates, manganese, bauxite and alumina, and tin. Iron ore was already included in Stabex, and will continue there for the duration of Stabex II as regards production and export fluctuations from deposits already worked; new mines however already fall under Sysmin. Minerals are thus covered only when exported in their raw state, ie up to the state of wirebars or ingots or the corresponding level for phosphates.

The scheme comes into effect in cases where there has been 'a substantial fall' in the production or exportearning capacity of a qualifying product that could 'seriously affect the development policy of the ACP state concerned by seriously compromising the profitability of an otherwise viable and economic line of production, thus preventing it from renewing at a normal rate or maintaining the production plant or export capacity'. An insertion made later in the Convention states that the 'substantial fall' shall be taken to mean 10 per cent (EEC-ACP 1981, article 52). Unlike Stabex, where the 'dependence threshold' relates to the previous year, for Sysmin the export dependence qualification relates 'as a general rule' to the earnings profile over the previous four years.

The amount budgeted for expenditure under the scheme is $280 \mathrm{mn}$ EUAs, with an additional $2 \mathrm{mn}$ added when Zimbabwe became an ACP state, to be disbursed in five approximately equal annual tranches of some $56 \mathrm{mn}$ EUAs. ${ }^{1}$ However, up to 50 per cent extra may be used from the allocation of the following year if the governments of EEC member states

\footnotetext{
'The standard average annual exchange rate between the EUA and the US $\$$ has moved as follows: $1981: 1 \mathrm{EUA}=\$ 1.116$ $1 \mathrm{EUA}=\$ 0.98$
} 
authorise it; also, any balance remaining at the end of each year is carried over automatically to the next. No country may receive more than half the aid provided in any one year. Resources provided under the Sysmin scheme are, unlike Stabex, only available as loans with fixed repayment conditions. These are in normal cases: 40 year maturity, 1 per cent annual interest charged, but a 10-year grace period for repayment of principal. Sysmin resources are, however, financed from exactly the same source as Stabex and EEC project aid in ACP countries, ie from the EDF, itself funded by direct contributions from the member states of the EEC. Again, unlike Stabex, Sysmin loan finance is available only for projects and programmes whose implementing conditions are identical to the EDF aid supplied to ACP states under their indicative aid programmes: the Sysmin chapter in the Convention refers to Title VII (basically EDF aid project procedure) for all matters requiring explanation. However, under Sysmin the need for rapid implementation is specifically recognised.

Applications for advances need to be based on estimates of falling production capacity expected over subsequent months. Moreover, the amount of aid made available is not necessarily related to the anticipated export earnings shortfall. Rather, the amount of aid is determined by the EEC Commission (not the applicant) 'in the light of the funds available, the nature of the projects or programmes proposed by the ACP states concerned and the possibilities of cofinancing' [EEC-ACP 1981, Title III, ch 2, article 54]. The money must normally be spent on supplies or the provision of services 'as a means of pre-financing projects and programmes'. Thus discretion remains substantially with the donor. The Commission alone decides upon the acceptability of the proposal and the amount of the loan. Only when the earmarked resources are converted into a project does the Commission require the approval (or rather the absence of an objection) from the EDF Committee, on which are represented the 10 member states.

\section{Experience so far}

An examination of the operation of the scheme so far reveals several problems. To begin with, the enumeration of products above is somewhat misleading. At the moment, there are no ACP countries that derive 15 per cent of their export revenue from either manganese or tin; the scheme applies, therefore, only to the other three products and is, in fact, overwhelmingly dominated by copper. So, the main beneficiaries of a scheme drawing on aid funds are comparatively better-off producers of copper (Papua New Guinea, Zambia and Zaire), and therefore its developmental impact on the poorer countries may be limited. On the other hand, the impact of the scheme in terms of the interests of the EEC countries is restricted by the funds available. In the recent past, two loans under the scheme have been agreed: one to Zaire for $40 \mathrm{mn}$ EUAs (some $\$ 56 \mathrm{mn}$ ) and another one to Zambia for $55 \mathrm{mn}$ EUAs (some $\$ 77 \mathrm{mn}$ ). In both cases, applications had been made for $140 \mathrm{mn}$ EUAs over five years; that is some $\$ 195 \mathrm{mn}$ and half of the total budget under the scheme. The requirements of investment in the copper industry in Zaire for 1983 are estimated at $\$ 250 \mathrm{mn}$; this would allow immediate rehabilitation of old and obsolete equipment and plant and expansion of productive capacity to recover to the 1974 high of 470,000 tons of copper (current production is about 425,0000 tons). The longer term requirement is estimated at $\$ 1.1$ bn [EIU 1982:12]. In the case of Zambia, investment requirements are estimated at $\$ 1.15$ bn for the five years of Lomé II [Fortin 1981:197].

The Zambian Sysmin drawing was fixed from the start by the Commission at 55 mn EUAs. Both Zambia's production and balance of payments difficulties (in the sense that the Zambian economy's dependence on copper exports was recognised as overwhelming) were taken into account in fixing the figure close to the maximum possible for a single ACP state in the circumstances (50 per cent of the accumulated tranches for the first two years). The drawing thus bears only a remote or accidental relation to the size of the real shortfall in the production and export sector.

Zaire's allocation of $40 \mathrm{mn}$ EUAs is smaller because the Commission considered Zaire's dependence on copper to be less crucial (it was deemed to be mitigated by the less adversely affected cobalt exports as well as agricultural products and diamonds); the Commission also considered that the technical conditions of mining were easier than in Zambia and that the ores were generally of higher grade. Apparently, all these factors influence the Commission's determination of the right to a transfer and of the scale of the transfer. Moreover, unlike the Zambian case, for Zaire the Commission at tached conditions to the Sysmin loan which bind the government to a new fiscal regime for the copper sector and consequently required a reorganisation of financial relations between the Kinshasa Government and the (albeit state-owned) mining company, Gécamines. These conditions were ultimately accepted because the World Bank (specifically in the mining sector and elsewhere) and the IMF were simultaneously proposing fiscal and macroeconomic adjustments as part of, respectively, a $\$ 500 \mathrm{mn}$ Gécamines rehabilitation and a major IMF standby agreement. The EEC Commission's conditionality fitted well into these proposals, although the scale of the contribution (40 mn EUAs as a loan) was of course rather small in comparison. As a result of these conditions, which in the case of Sysmin were a prerequisite for the loan application to go ahead, the government agreed in 
September 1981 to introduce new fiscal laws. No export duties were to be imposed on copper; corporation tax was to be applied only on Gécamines' profits (operating surpluses) until 1983; and more general fiscal reforms were to be introduced gradually under the guidance of the IMF. Both the Zaire Government and the EEC were considering possibilities of direct marketing of output by Gécamines as part of the Sysmin package.

Two new applications - Rwanda for tin and Guyana for white bauxite - both for 1981 downturns, were still in the very early stages of processing in mid-1982. Preliminary reports suggested that the Guyana operation would proceed, as nearly all the bauxite was exported to the EEC, but the Rwanda case was more problematic as mine exhaustion was the key factor in the downturn of production.

In the case of both Zambia and Zaire, it will be noted, the aid under Sysmin represents only a fraction of the capital requirements. It is, furthermore, solely for the rehabilitation of existing capacity or some expansion of treatment capacity; the financing of exploration - itself a highly cost-effective use of aid - is not contemplated. There may be no formal obstacle to the inclusion of exploration projects within Sysmin but the fact that it is linked to serious disruptions in production, exports, or export earnings tends to bias it in favour of non-exploration uses. As indicated above, a separate chapter in the Convention refers to technical and financial assistance for research and exploration, but no specific scheme is included. As also indicated, another form of support for mining activities in the Convention is contained in Article 59, which states that the EIB can finance mining and energy investment projects in accordance with its general rules of operation. Zambia has in fact been able to secure partial EIB support for an expansion of treatment capacity in the form of a new leaching plant. The overall cost is $\$ 250 \mathrm{mn}$, of which EIB provides $\$ 26 \mathrm{mn}$. The EIB facility has also been used by Papua New Guinea for the Ok Tedi project. Use of the facility in that case was not necessary in order to render the project viable. It was simply looked upon as a way of gaining access to concessional risk capital.

It is easy - perhaps too easy - to be critical of the limited impact achieved by the measures designed to promote cooperation in the mineral-producing sector during Lomé II. There is a sense in which the effects of the continuing recession have overwhelmed small, partial programmes of this kind. That the facilities introduced were intended to promote European interests as consumers as well as to assist ACP producers is not in dispute, nor that the $\mathrm{ACP}$ countries eligible to benefit are likely to be few. The Commission itself may also need a little time to formulate procedures for the operation of such new facilities, and the ACP countries time to become familiar with them. There is a sense, therefore, in which more time - and more normal times - may be required before the facilities can be judged fairly.

\section{Proposals for New Initiatives}

In that context, it may be thought premature to ask whether there may be other initiatives in the mineral sector that could be of mutual benefit to the EEC and the ACP countries. In any case, the truthful answer to that question is that we do not know; for, while it is possible to conceive schemes that would appear to have a good probability of being mutually beneficial, it is not certain that the precise measures that would be required to give practical expression to these concepts can be designed and successfully negotiated.

Nevertheless, there are three types of activity which can be mentioned as areas of potential mutual advantage where new initiatives might be considered. These are: the promotion of exploration; emergency purchases of minerals from selected ACP countries when prices are exceptionally low; and the encouragement of mineral revenue stabilisation funds.

\section{Exploration}

It has frequently been asserted that, mainly because of their assessment of the 'political risk' involved, investment in exploration by the major European mining companies in developing countries, particularly the ACP countries, has declined sharply. The statistics most often quoted in support of this contention purport to show that, whereas in 1961 exploration in such countries absorbed 57 per cent of the total exploration budget, by 1973-75 the comparable figure had fallen to 13.5 per cent. The future consequences are potentially serious both for the mineral-importing countries of the EEC and for many of the mineralexporting countries of the ACP. When Europe recovers from recession, the EEC countries may find themselves experiencing severe shortages of certain minerals and, in any event, will have to pay higher prices for their imports than would have been necessary had the most economic sources of supply been developed. The ACP group of countries, so the argument goes, would suffer through a failure to realise the mining investment, production, and foreign exchange earnings that their natural resource endowment in other circumstances would have made possible. The proposals for dealing with this situation have largely centred around international schemes to provide political risk insurance for the investing companies on the one hand and, on the other, the threat of severe sanctions to be imposed against any host country government which is judged to have altered unilaterally the terms under which mining 


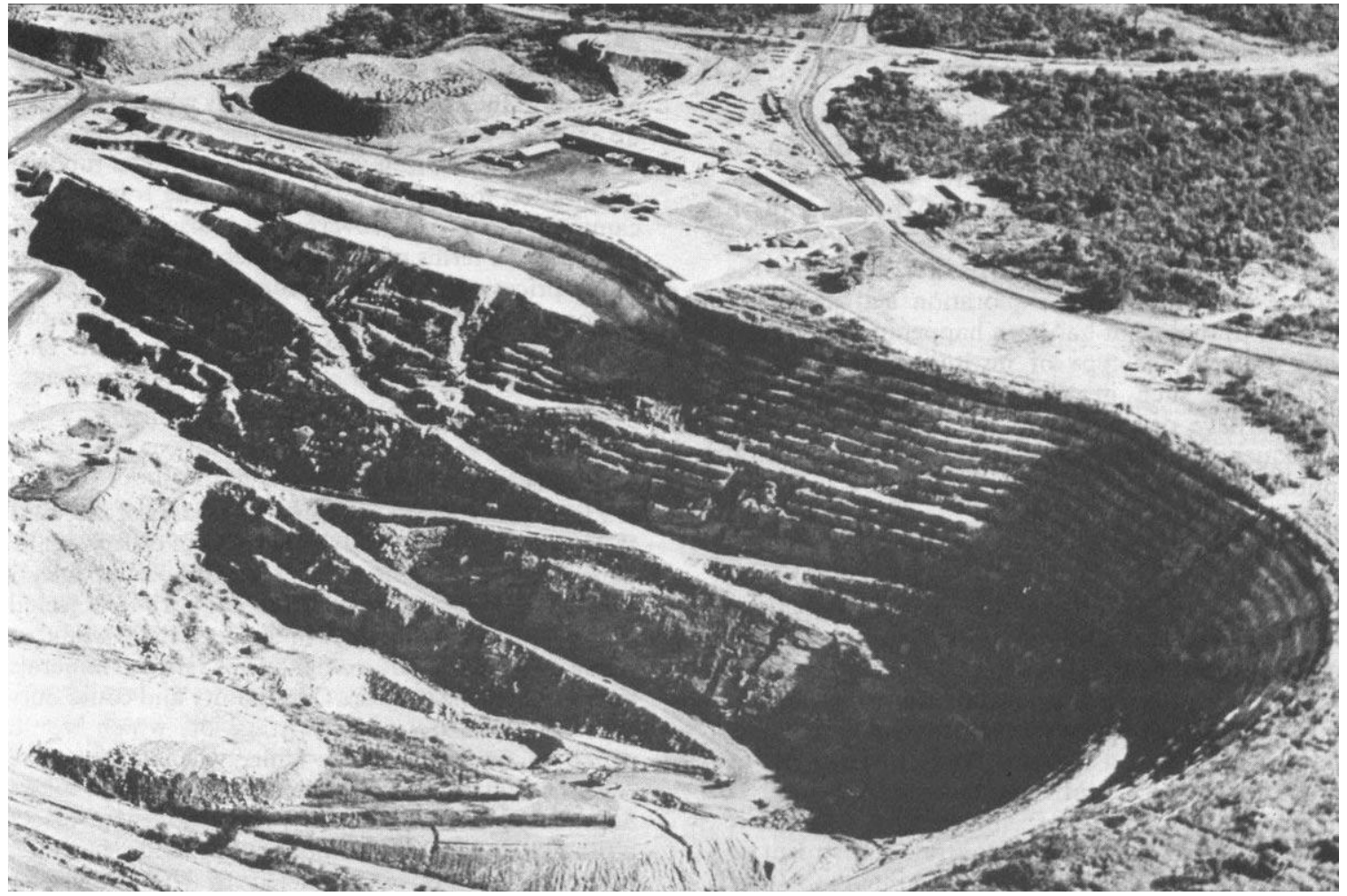

Zambia - the open pit at Chambishi. Below: left - the converter aisle in the smelter at Mufulira: tight - aspect of an underground operation.

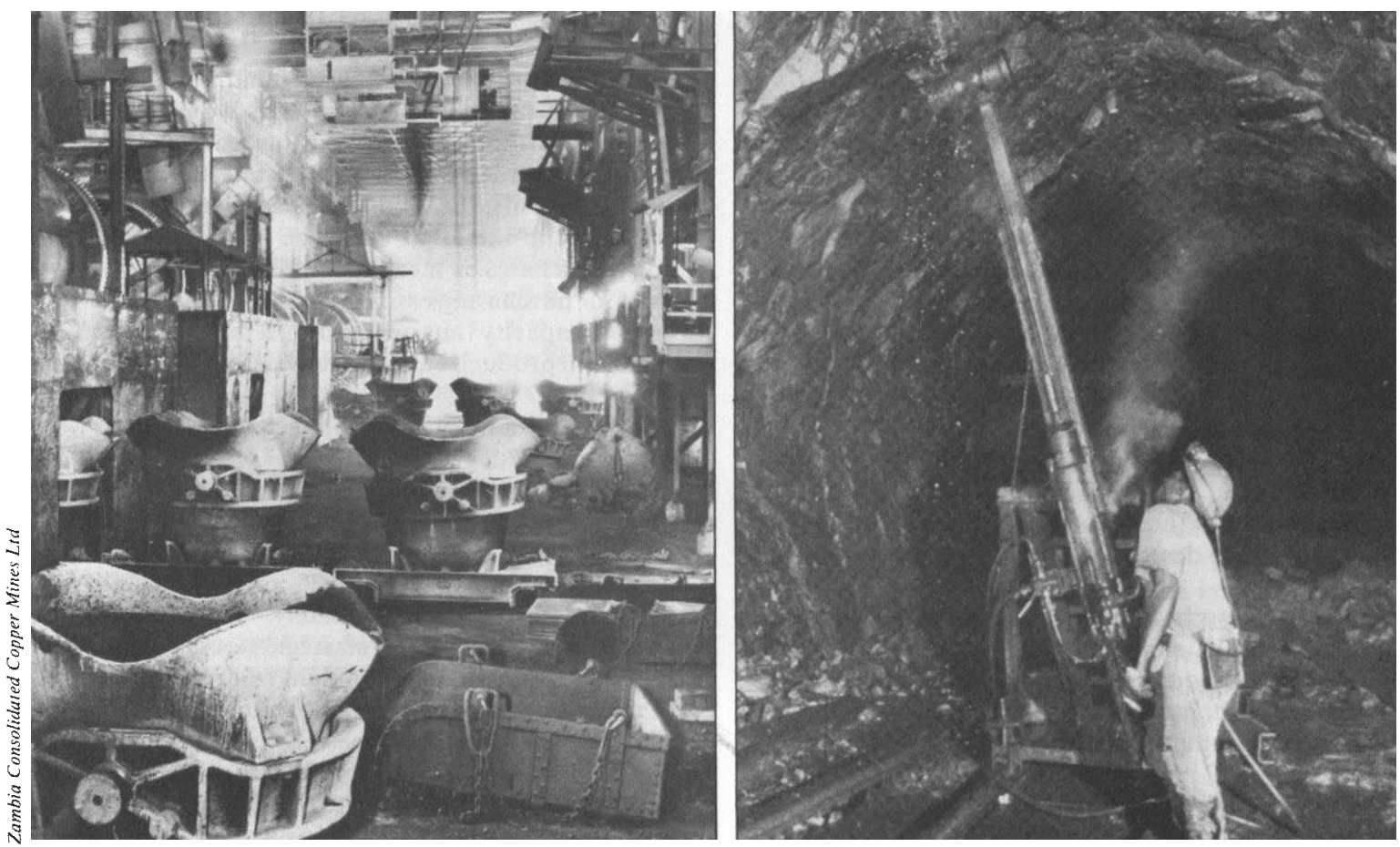


investment had earlier taken place [European Mining Companies 1976].

More recently, both the factual description of what has been happening to the level and pattern of exploration activity in the Third World, and the accuracy of the diagnosis upon which the prescription of insurance-type cures was based, have been questioned. In particular, it has been argued a) that the decline in Third World exploration activity is not general; $b$ ) that what has been happening has been a basic shift in the type of institution financing or undertaking such investment; and c) that where declines have occurred, this has been as much the consequence of weak market conditions as of a general apprehension of political risk.

The most detailed analysis of the problem has been conducted by Radetzki [1982]. His conclusions are that the share of global direct foreign investments in the mineral sector allocated to developing countries (mainly from the USA and the EEC countries) was substantially curtailed some time before 1966 , but that it then remained relatively constant until the present. Moreover, there is a contrast between the declining role of developing countries as hosts to foreign direct investment in mining and their continued importance in terms of production and overall investment in minerals. Two factors have accounted for this apparent paradox. The first has been the increasing role of national enterprise in developing country minerals. The second and more important factor has been the large-scale substitution of loans for equity in financing mineral projects in developing countries.

Even if Radetzki's explanation is accepted, however, three further possibilities remain and have at different times been urged. First, that even though developing countries have maintained their share of overall investment and production, their share of exploration expenditure has been decreasing and this, after an 8-10 year time lag, will eventually affect production. Second, that even where the quantity of exploration expenditure has been maintained, its quality has fallen off. And third, that whatever the global figures may show, certain specific ACP countries are not attracting (or managing to finance themselves) the amount of exploration that their potential mineral resources would appear to deserve.

It is these hypotheses that have given rise to the argument that a supplementary and new form of scheme may be required for dealing with the problem. In particular, it has been argued that, since future consumers of mineral products are the most certain beneficiaries of any expanded or more economic source of supply, it is they who should bear the relatively very small burden of financing the earlier phases in the mineral exploration effort. Or, put another way, the cost of discovering new sources of exhaustible mineral supplies would become a normal element in the cost of those products which are using up existing sources of supply. It has been pointed out also that, whereas a single potential customer funding exploration for the mineral in which he is interested cannot be certain of recovering for himself the value of his outlay in terms of increased security of supply or lower prices, the wider the community of potential customers who undertake such funding the more certain are they collectively to reap the benefit. This makes such schemes, in concept, singularly appropriate for Community initiatives.

\section{Purchases}

An EEC scheme for emergency purchases of minerals from selected $\mathrm{ACP}$ countries at times of exceptionally depressed prices would not be a buffer stock scheme. It would be a scheme to provide support to selected mineral producers in times of distress which would at the same time provide a stockpile of selected minerals that would be held by the Community and could only be released in times of shortage or, which would probably be at the same time, when prices were exceptionally high. To that extent, the scheme might have an effect, marginally, of stabilising prices although that would not be its main purpose. Purchases would be restricted to those minerals exported by ACP countries in respect of which the EEC, as a whole, was a major net importer. The scale of any purchases less disposals of any one mineral would be limited, apart from budgetary considerations, to a certain proportion of the Community's net annual imports of that mineral. Purchases would be funded not by loan finance but out of an enlarged EDF or possibly from a special fund into which the proceeds of sales would also be paid. If a special fund were to be created, consideration could be given to paying for stock purchases by means of credits that could only be used for purchasing exports from EEC industries with unused capacity thus generating, it might be assumed, increased production within both groups of countries.

The possible advantages of the scheme would be that, in times of depressed mineral prices, productive activity would be maintained at a higher level than might otherwise be possible in the mineral exporting country, with some expectation that second-stage demand for the exports of EEC countries would also be increased. Commensurately, the EEC would acquire a moderate-sized strategic stockpile of certain important minerals that it might run short of in times of improved demand or, possibly, interrupted supply. The scheme might be expected to have a beneficial effect in stabilising the export earnings of certain developing countries. Started at a time when most mineral prices in real terms are below historical trend 
prices, the net cost of the scheme over time might be expected to be low. Nor is the implementation of such a scheme as unlikely as it might have appeared earlier. Though stockpiles are not yet held at Community level, several member states maintain stockpiles of strategic minerals and even the British Government was reported to have started stockpiling in February 1983 [Financial Times, 14 February].

The potential difficulties and disadvantages of such a scheme, however, cannot be ignored. National policies within the EEC towards the holding of strategic stocks differ widely. Purchases that might prevent production cutbacks could delay price recovery, even if the stocks were held off the market. And, in terms of development aid, both EEC and ACP countries would have to be convinced that funds tied up in stockholding, even if they might eventually result in a profit, could not be put to better developmental use.

\section{Mineral revenue stabilisation funds}

The idea behind the encouragement (or insistance) upon the use of mineral revenue stabilisation funds can best be described as one of benign conditionality. Such funds are established as a domestic measure to counteract the instability of earnings from mineral exports which itself arises from the tendency of mineral prices to fluctuate. The purpose of a mineral revenue stabilisation fund is thus primarily to provide insurance against an inability to maintain development programmes in periods of slump, but it also helps to regulate domestic demand stimulated by government expenditure by preventing such demand from building up in boom periods. The fund thus contributes to overall fiscal stabilisation and to monetary stability, usually by sterilising 'excess' inflows in Central Banks deposits or direct investments in foreign assets. Conversely, the fund is run down by releasing money into the annual budget at a controlled rate when mineral revenues are low.

It seems unquestionable that such a fund, wisely operated (like the Mineral Resources Stabilisation Fund in Papua New Guinea), can have beneficial effects. Whether the establishment of such funds can be made a condition of EEC aid in the mineral sector seems more doubtful, unless the EEC at times of depressed prices itself provides part of the initial resources. In current international economic conditions, very few ldc producers could themselves be in a position to build up such funds. However, as Philip Daniel has pointed out, ${ }^{2}$ this might be an easy time for an ldc government to put the required machinery in place, since the budgetary 'cost' of deferring expenditure would not be incurred until some future upturn in commodity prices.

\section{References}

EEC, 1979, The Courier, no 58, Commission of the European Communities, Brussels, November

EEC-ACP, 1981, The Second ACP-EEC Convention, ACPEEC Council of Ministers, Brussels

EIU, 1982, Quarterly Economic Review of Zaire, Rwanda, Burundi, 2nd Quarter, London

European Mining Companies, 1976, Raw Materials and Political Risk, submission to the President of the European Communities by a group of European mining companies, June

Financial Times, 1983, London, 14 February

Fortin, C., 1981,'The mining sector', Technical Paper no 16 in Basic Needs in an Economy under Pressure, findings and recommendations of the ILO/JASPA basic needs mission to Zambia, vol II, Addis Ababa

Goldstein, M., 1982, 'The role of the EEC in ACP states' mineral development' in Legal and Institutional Arrangements in Minerals Development, Mining Journal Books, London

Radetzki, M., 1982, 'Has political risk scared mineral investment away from the deposits in developing countries?', World Development, vol 10 no 1

${ }^{2}$ Personal communication, 1983. 